\title{
Bottleneck Effect Explained by Le Bail Refinements: Structure Transformation of Mg-CUK-1 by Confining $\mathrm{H}_{2} \mathrm{O}$ Molecules
}

\author{
Elí Sánchez-González ${ }^{1,2,+}{ }^{,}$J. Gabriel Flores ${ }^{1,3,4,+}{ }^{+}$, Julio C. Flores-Reyes ${ }^{5}$, \\ Ivette Morales-Salazar ${ }^{5}$, Roberto E. Blanco-Carapia ${ }^{5}$, Mónica A. Rincón-Guevara ${ }^{6}$, \\ Alejandro Islas-Jácome ${ }^{5}{ }^{(D)}$, Eduardo González-Zamora ${ }^{5, *}{ }^{(}$, Julia Aguilar-Pliego ${ }^{3, *}$ and \\ Ilich A. Ibarra $1, * \mathbb{D}$
}

1 Laboratorio de Fisicoquímica y Reactividad de Superficies, Instituto de Investigaciones en Materiales, Universidad Nacional Autónoma de México, Circuito Exterior S/N, Ciudad Universitaria, Coyoacán, Ciudad de México C.P. 04510, Mexico; sanchez.gonzalez.eli@gmail.com (E.S.-G.); gabriel_flores_aguilar@hotmail.com (J.G.F.)

2 Institute for Integrated Cell-Material Sciences (WPI-iCeMS), Kyoto University, Yoshida, Sakyo-ku, Kyoto 606-8501, Japan

3 Departamento de Química Aplicada, Universidad Autónoma Metropolitana-Azcapotzalco, San Pablo 180, Col. Reynosa-Tamaulipas, Azcapotzalco, Ciudad de México C.P. 02200, Mexico

4 Instituto de Catálisis y Petroleoquímica, ICP-CSIC, C/ Marie Curie, 2, C.P. 28049 Madrid, Spain

5 Departamento de Química, Universidad Autónoma Metropolitana-Iztapalapa, San Rafael Atlixco 186, Col. Vicentina, Iztapalapa, Ciudad de México C.P. 09340, Mexico; flores.reyes.jc@gmail.com (J.C.F.-R.); ivette649_tatu@hotmail.com (I.M.-S.); edreyblanco@gmail.com (R.E.B.-C.); aij@xanum.uam.mx (A.I.-J.)

6 Departamento de Biotecnología, Universidad Autónoma Metropolitana-Iztapalapa, San Rafael Atlixco 186, Col. Vicentina, Iztapalapa, Ciudad de México C.P. 09340, Mexico; monicarinconguevara@gmail.com

* Correspondence: egz@xanum.uam.mx (E.G.-Z.); apj@correo.azc.uam.mx (J.A.-P.); argel@unam.mx (I.A.I.)

$\dagger$ Both authors contributed equally to this work.

Received: 12 January 2020; Accepted: 8 April 2020; Published: 14 April 2020

\begin{abstract}
The structure transformation of Mg-CUK-1 due to the confinement of $\mathrm{H}_{2} \mathrm{O}$ molecules was investigated. Powder X-ray diffraction (PXRD) patterns were collected at different $\mathrm{H}_{2} \mathrm{O}$ loadings and the cell parameters of the $\mathrm{H}_{2} \mathrm{O}$-loaded Mg-CUK-1 material were determined by the Le Bail strategy refinements. A bottleneck effect was observed when one hydrogen-bonded $\mathrm{H}_{2} \mathrm{O}$ molecule per unit cell $(18 \%$ relative humidity $(\mathrm{RH}))$ was confined within Mg-CUK-1, confirming the increase in the $\mathrm{CO}_{2}$ capture for Mg-CUK-1.
\end{abstract}

Keywords: MOFs; structure transformation; PXRD Le Bail refinements

\section{Introduction}

Global warming is one of the greatest risks to human civilization. In particular, the growing levels of anthropogenic carbon dioxide $\left(\mathrm{CO}_{2}\right)$ emissions from fossil fuel combustion [1] directly influence our environment, triggering the continuous rise of temperatures across the planet. Only in 2017, worldwide $\mathrm{CO}_{2}$ emissions from fossil fuel combustion augmented by approximately $2 \%$ compared with the 2015-2016 period [2]. Currently, governments are working together on a worldwide basis to encourage the development of new technologies for a more efficient and effective $\mathrm{CO}_{2}$ capture [3]. Porous metal-organic frameworks (MOFs) or porous coordination polymers (PCPs) are among the most promising candidates for $\mathrm{CO}_{2}$ capture because their carbon dioxide sorption properties can be more broadly tuned than classical mesoporous materials (e.g., zeolites) [4]. Current synthetic approaches to further increase sorption selectivity towards carbon monoxide include the incorporation 
of open metal sites that can enhance molecular sorption, and by functionalizing the organic linker with the Lewis basic groups (e.g., amines and alcohols) [5]. Very recently, thorough investigations were also made to enhance the $\mathrm{CO}_{2}$ capture of MOFs by using the synergistic effects caused by pre-confining small amounts of polar molecules in their pores [6-8]. In this regard, we previously showed that the confinement of small amounts of $\mathrm{H}_{2} \mathrm{O}$ in a series of MOFs (functionalized with hydroxo functional groups, $\mu_{2}-\mathrm{OH}$ ) steadily resulted in improved $\mathrm{CO}_{2}$ capture properties [9]. The confined $\mathrm{H}_{2} \mathrm{O}$ molecules are well-ordered in the pore-structure of these $\mu_{2}-\mathrm{OH}$ functionalized MOFs, working as preferential adsorption sites for the subsequent $\mathrm{CO}_{2}$ molecules [10]. In this communication, we describe the structure transformation of Mg-CUK-1 (CUK for Cambridge University-KRICT, see SM, Figure S1) [11] due to the confined $\mathrm{H}_{2} \mathrm{O}$ molecules within its pores, which previously demonstrated enhanced $\mathrm{CO}_{2}$ capture properties [12,13].

\section{Materials and Methods}

\subsection{Material Synthesis}

Mg-CUK-1 $=\left[\mathrm{Mg}_{3}(\mathrm{OH})_{2}(2,4-\mathrm{PDC})_{2}, 2,4-\mathrm{PCD}=2,4\right.$-pyridinecarboxylate $]$ was synthesized following the previously reported procedure in [11]: 2,4-Pyridinedicarboxlic acid (170 mg, $1.0 \mathrm{mmol})$ and $\mathrm{KOH}\left(2.0 \mathrm{M}, 2.0 \mathrm{~cm}^{3}\right)$ in $\mathrm{H}_{2} \mathrm{O}$ were added to a stirred solution of $\mathrm{Mg}\left(\mathrm{NO}_{3}\right)_{2},(380 \mathrm{mg}, 1.5 \mathrm{mmol})$ in $\mathrm{H}_{2} \mathrm{O}\left(3 \mathrm{~cm}^{3}\right)$ to give a viscous, opaque, slurry mixture. The reaction mixture was placed inside a Teflon-lined Easy-Prep vessel and heated at $472 \mathrm{~K}$ for $35 \mathrm{~min}$ in a MARS microwave (CEM Corp.). The reaction temperature was monitored using a fiber-optic sensor. After cooling down to room temperature ( $30 \mathrm{~min})$, the crystalline solid was purified by short $(3 \times 20 \mathrm{~s})$ cycles of sonication in fresh $\mathrm{H}_{2} \mathrm{O}$, followed by the decanting of the slurry supernatant. Large, colorless prismatic crystals were isolated (average yield: $124 \mathrm{mg}$ ). TGA and PXRD were carried out and confirmed the nature of the synthesized material and its purity (see Figures S2 and S3, SM), and the estimated BET surface area of the activated Mg-CUK- $1\left(100{ }^{\circ} \mathrm{C}\right.$ at $1 \times 10^{-4}$ bar and $\left.2 \mathrm{~h}\right)$.

\subsection{Methods}

Adsorption Isotherms for $\mathrm{CO}_{2}$. Ultra-pure grade (99.9995\%) $\mathrm{CO}_{2}$ gas was purchased from PRAXAIR. $\mathrm{CO}_{2}$ adsorption isotherms at $196 \mathrm{~K}$ and up to 1 bar were carried out on a Belsorp mini II analyzer under high vacuum.

Water-loading within Mg-CUK-1. $\mathrm{H}_{2} \mathrm{O}$ vapor loadings were performed by a dynamic method, using air gas as the carrier gas, and by using a DVS Advantage 1 instrument from Surface Measurement Systems (mass sensitivity: $0.1 \mathrm{mg}$, relative humidity $(\mathrm{RH})$, accuracy: $0.5 \% \mathrm{RH}$, vapor pressure accuracy: $\left.0.7 \% \mathrm{P} / \mathrm{P}_{0}\right)$. Mg-CUK-1 samples were activated at $100{ }^{\circ} \mathrm{C}$ for $1 \mathrm{~h}$ under flowing dry $\mathrm{N}_{2}$. The water contents within Mg-CUK-1 analyzed were 25\% RH, 22\% RH, 20\% RH and 18\% RH.

Powder X-ray diffraction patterns were collected on a Rigaku Diffractometer, Ultima IV, with a $\mathrm{Cu}-\mathrm{K} \alpha 1$ radiation $(\lambda=1.5406 \AA)$ using a nickel filter. These were obtained from $5^{\circ}$ to $50^{\circ}$ in $2 \theta$, with $0.02^{\circ}$ steps at a $0.08^{\circ} \mathrm{min}^{-1}$ scan rate. Profile refinements were performed based on the previously reported Mg-CUK-1-hydrated structure data using the FullProf program (structure NUDLIJ from CCDC database) $[14,15]$.

\section{Results}

Mg-CUK-1 is assembled from the coordination of $\mathrm{Mg}(\mathrm{II})$ metal centers and 2,4-pyridinedicarboxylate ligand. Mg-CUK- 1 crystallizes in the space group $\mathrm{P} 21 / n$ and it is constructed around trinuclear $\left[\mathrm{Mg}_{3}\left(\mu_{3}-\mathrm{OH}\right)\right]$ building blocks (see Figure S1, inset) [11]. Each $\mathrm{Mg}$ (II) metal center shows an octahedral coordination environment and links into infinite chains of edge- and vertex-sharing $\mathrm{Mg}_{3} \mathrm{OH}$ triangles. Mg-CUK-1 shows a 3-D framework structure with diamond-shaped pore dimensions of approximately $8.1 \times 10.6 \AA$ (see Figure S1). The estimated BET area $(0.005<\mathrm{P} / \mathrm{P} 0<0.15)$ was equal to $604 \mathrm{~m}^{2} \mathrm{~g}^{-1}$, with a corresponding pore volume of $0.22 \mathrm{~cm}^{3} \mathrm{~g}^{-1}$. 
The water-loading dependence of the porosity of Mg-CUK-1 was analyzed based on the reported $[12,13]$ water adsorption isotherm data. For that purpose, the experimental PXRD patterns were collected at different $\mathrm{H}_{2} \mathrm{O}$ loadings (see SM, water-loading within Mg-CUK-1, Figure S4) and the cell parameters of the $\mathrm{H}_{2} \mathrm{O}$-loaded material (Mg-CUK-1) were determined by the Le Bail methodology (FullProf program; see SM, PXRD profile refinement of Mg-CUK-1, Figures S5-S8) [14,15]. The so-obtained evolution of the cell parameters corroborated the soft crystal properties of Mg-CUK-1: the $b$-axis increases with the water content from 12.334 to $13.435 \AA$ (see Figure S9). Such a change occurred from the anhydrous form to the eight $\mathrm{H}_{2} \mathrm{O} / \mathrm{UC}$-loaded versions (Table S1). We indeed observed a dramatic reduction in the accessible space when the $\mathrm{H}_{2} \mathrm{O}$ concentration increased (see Table 1 and Figure S10).

The reduction in the minimum channel length is considerably more drastic in the $b$ direction, which can be associated with the position of the hydroxo groups $\left(\mu_{2}-\mathrm{OH}\right)$ that are only present in the $b$ direction of the channel. The minimum channel length in the $b$ direction is reduced from $6.62 \AA$, in the empty material, to approximately $2.56 \AA$, with eight water molecules per unit cell, corresponding to more than a $50 \%$ reduction in the size of the channel diameter (Table 1). These eight water molecules correspond to one $\mathrm{H}_{2} \mathrm{O}$ molecule per hydroxo group and, at this point, the inclusion of $\mathrm{CO}_{2}$ is anticipated to not be possible. Since the kinetic diameter of $\mathrm{CO}_{2}$ is $3.3 \AA$ (Figure 1), this essentially inhibits the direct passage of the $\mathrm{CO}_{2}$ molecules through the Mg-CUK-1 network, and therefore results in zero adsorption of $\mathrm{CO}_{2}$.

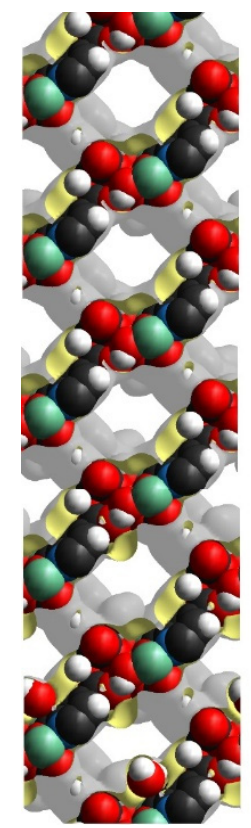

(a)

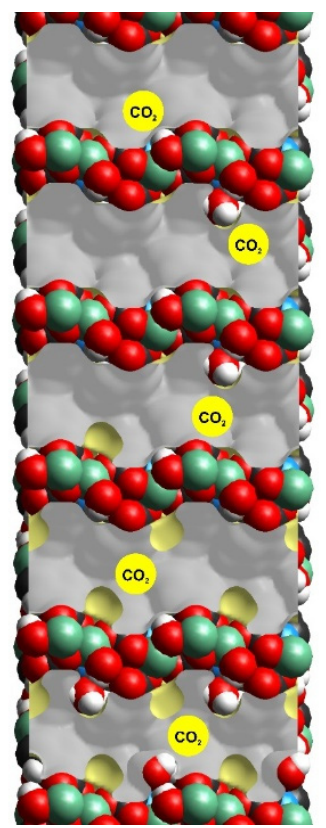

(b)

Figure 1. Crystal structures of Mg-CUK-1 with different $\mathrm{H}_{2} \mathrm{O}$ molecule loadings, from top to bottom, none, 1, 2, 4 and 8 water molecules per unit cell. (a) View through the $a$-axis showing the hydrogen-bonded $\mathrm{H}_{2} \mathrm{O}$ molecules to the hydroxo functional groups $\left(\mathrm{H}_{2} \mathrm{O} \cdots \mathrm{OH}-\mu_{3}\right)$, and (b) side view of the channel (through the $c$-axis) and accessible surface, yellow circles represent $\mathrm{CO}_{2}$ kinetic diameter. 
Table 1. Mg-CUK-1 one-dimensional channel dimensions at different $\mathrm{H}_{2} \mathrm{O}$ molecule loadings. The window dimensions $l_{\mathrm{b}}$ and $\mathrm{l}_{\mathrm{c}}(\AA)$ were estimated using a 0.002 au isosurface with CrystalExplorer $[14,15]$.

\begin{tabular}{|c|c|c|c|c|c|}
\hline Material & $\mathrm{H}_{2} \mathrm{O} / \mathrm{UC}$ & $l_{b}(\AA)$ & $1_{c}(\AA)$ & $\mathrm{O}_{\mathrm{H} 2 \mathrm{O}-} \mathrm{O}_{\mathrm{H} 2 \mathrm{O}}(\AA)$ & Pore \\
\hline Mg-CUK-1 & 0 & 6.62 & 6.51 & - & Accessible \\
\hline Mg-CUK- $1 \cdots 1 \mathrm{H}_{2} \mathrm{O}$ & 1 & 4.43 & 6.52 & 20.5 & Accessible \\
\hline $\mathrm{Mg}-\mathrm{CUK}-1 \cdots 2 \mathrm{H}_{2} \mathrm{O}$ & 2 & 4.43 & 6.52 & 6.5 or 9.5 & Restrained \\
\hline $\mathrm{Mg}-\mathrm{CUK}-1 \cdots 4 \mathrm{H}_{2} \mathrm{O}$ & 4 & 4.68 & 6.61 & 4.6 or 6.5 & Restrained \\
\hline Mg-CUK- $1 \cdots 8 \mathrm{H}_{2} \mathrm{O}$ & 8 & 2.56 & 6.61 & 4.6 & Non-accessible \\
\hline
\end{tabular}

\section{Discussion}

Interestingly, four and two $\mathrm{H}_{2} \mathrm{O}$ molecules interacting via hydrogen bonding to $\mathrm{Mg}$-CUK-1 (molecules per unit cell) lead to a window reduction of 4.68 and $4.43 \AA$, respectively (Table 1 ). However, the minimum distance between two adjacent water molecules is 3.3 and $6.7 \AA$ for $\mathrm{Mg}-\mathrm{CUK}-1$ with four and two water molecules, respectively. According to this, the path for the diffusion of $\mathrm{CO}_{2}$ is restrained (Figure 1) and a low $\mathrm{CO}_{2}$ adsorption is expected. Following this trend, an increase in the distance between the water molecules within the pore can result in a favorable space for $\mathrm{CO}_{2}$ to interact with the $\mathrm{H}_{2} \mathrm{O}$ molecules. When there is one hydrogen-bonded $\mathrm{H}_{2} \mathrm{O}$ molecule per unit cell, the pore-window is reduced to approximately $4.43 \AA$ and the distance between two water molecules increases to $20.5 \AA$ (Table 1). This can provide enough free space for the $\mathrm{CO}_{2}$ molecules to diffuse within the pore-window and, as we previously reported, a "bottleneck effect" occurs [16,17]. This effect is expected to accommodate the $\mathrm{CO}_{2}$ molecules more efficiently, by partially obstructing the pore-windows of Mg-CUK-1. Indeed, this particular configuration (one hydrogen-bonded $\mathrm{H}_{2} \mathrm{O}$ molecule per unit cell) corresponds to $18 \%$ of relative humidity $(\mathrm{RH})$, according to the water adsorption isotherm [12,13]. Remarkably, Mg-CUK-1 revealed a 1.8-fold increase in $\mathrm{CO}_{2}$ capture from $4.6 \mathrm{wt} \%$ to $8.5 \mathrm{wt} \%$ in the presence of $18 \%$ RH [12] (See Figure S11).

\section{Conclusions}

The structure transformation of Mg-CUK-1 by the incorporation (confinement) of different amounts of water molecules was successfully demonstrated by PXRD (Le Bail methodology refinements). The confinement of one hydrogen-bonded $\mathrm{H}_{2} \mathrm{O}$ molecule per unit cell $(18 \% \mathrm{RH})$ produces a bottleneck effect with adequate pore dimensions $(4.43 \AA)$ for the proper diffusion of $\mathrm{CO}_{2}$ molecules. Such a structure transformation corroborates a 1.8-fold increase in $\mathrm{CO}_{2}$ capture from $4.6 \mathrm{wt} \%$ to $8.5 \mathrm{wt} \%$, as previously reported for Mg-CUK-1 [12].

Supplementary Materials: The following are available online at http://www.mdpi.com/1996-1944/13/8/1840/s1, Figure S1: Crystal structure of Mg-CUK-1 viewed through the a-axis, depicting the one-dimensional channels with the hydroxyl group in the $\mathrm{b}$ direction. Inset, trinuclear $\mathrm{Mg}(\mathrm{II})$ building block with the hydroxyl group pointing towards the center of the channel, Figure S2: Thermogravimetric analysis profile of Mg-CUK-1 as synthesized, under $\mathrm{N}_{2}$ atmosphere, Figure S3: PXRD pattern of Mg-CUK-1 as synthesized (blue trace) and simulated (black trace). The reported hydrated Mg-CUK-1 structure was used for the simulated pattern (CCDC structure NUDLIJ), Figure S4: Comparison of Mg-CUK-1 PXRD patterns loaded at different relative humidity values: $18 \%, 20 \%$, $22 \%$ and $25 \%$ RH. Inset shows 011 plane reflection, Figure S5: Profile refinement of the Mg-CUK-1 PXRD pattern loaded at $25 \% \mathrm{RH}$, approximately 8 water molecules per unit cell, Figure S6: Profile refinement of the Mg-CUK-1 PXRD pattern loaded at $22 \% \mathrm{RH}$, approximately 4 water molecules per unit cell, Figure S7: Profile refinement of the Mg-CUK-1 PXRD pattern loaded at 20\% RH, approximately 2 water molecules per unit cell, Figure S8: Profile refinement of the Mg-CUK-1 PXRD pattern loaded at $18 \% \mathrm{RH}$, approximately 1 water molecules per unit cell, Figure S9: Comparison of the obtained cell parameter for the Mg-CUK-1 loaded at different relative humidity values: $18 \%, 20 \%, 22 \%$ and $25 \% \mathrm{RH}$. The cell parameters of the de-hydrated sample are included at $0 \%$ $\mathrm{RH}$, these parameters were taken from a different structure (structure NUDLOP01) than the one the refinements were based on (structure NUDLIJ), Figure S10: Side view of the channel through the c-axis, marking the distance between adjacent water molecules at different $\mathrm{H}_{2} \mathrm{O}$ loadings (from top to bottom 1, 2, 4 and $8 \mathrm{H}_{2} \mathrm{O}$ per unit cell), Figure S11: (a) Kinetic $\mathrm{CO}_{2}$ uptake experiment performed at $303 \mathrm{~K}$ with a $\mathrm{CO}_{2}$ flow of $60 \mathrm{~mL} \mathrm{~min}^{-1}$; (b) kinetic $\mathrm{CO}_{2}$ uptake experiments carried out at $18 \% \mathrm{RH}$ at $303 \mathrm{~K} ; \mathrm{H}_{2} \mathrm{O}$ (blue line) and $\mathrm{H}_{2} \mathrm{O}+\mathrm{CO}_{2}$ (red line) [12], Table S1: Refinement parameters of the Mg-CUK-1 structure at different water loadings. 
Author Contributions: E.S.-G. designed the PXRD experiments and refinements. J.G.F. calculations and corrections. I.M.-S., R.E.B.-C., J.C.F.-R. and M.A.R.-G. performed the $\mathrm{CO}_{2}$ capture experiments. J.A.-P. revised the final version of the manuscript. A.I.-J., E.G.-Z. and I.A.I. are the responsible researchers, who wrote the manuscript, and to whom correspondence must be addressed. All authors have read and agreed to the published version of the manuscript.

Funding: This research was funded by CONACYT, grant number 1789.

Acknowledgments: I.A.I. acknowledges PAPIIT-UNAM-Mexico (IN101517) and CONACYT (1789) for financial support. U. Winnberg (ITAM) for scientific discussions and G. Ibarra-Winnberg for bringing scientific insights to this contribution. L.L.-R. acknowledges CONACyT-México for financial support (CB-2016-255819), PRODEP-SEP for covering the associated Article Processing Charges and Publication Fees, and PRODEP-SEP also for financial support (Proyecto para fortalecimiento de CA's). A.I.-J. acknowledges UAM-I for his visiting professor position (40966). E.G.-Z. thanks CONACyT-México (CB-2014-236879) for financial support.

Conflicts of Interest: The authors declare no conflict of interest. The founding sponsors had no role in the design of the study, in the collection, analyses, or interpretation of data, in the writing of the manuscript, and in the decision to publish the results.

\section{References}

1. Chu, S. Carbon Capture and Sequestration. Science 2009, 325, 1599. [CrossRef] [PubMed]

2. National Oceanic and Atmospheric Administration (NOAA). Available online: https://www.esrl.noaa.gov/ gmd/ccgg/trends/?utm_source=www.uoota.com (accessed on 31 December 2018).

3. Ibrahim, M.H.; El-Naas, M.H.; Zhang, Z.; Van der Bruggen, B. $\mathrm{CO}_{2}$ Capture Using Hollow Fiber Membranes: A Review of Membrane Wetting. Energy Fuels 2018, 32, 963-978. [CrossRef]

4. Nuñez, A.J.; Shear, L.N.; Dahal, N.; Ibarra, I.A.; Yoon, J.W.; Hwang, Y.K.; Chang, J.-S.; Humphrey, S.M. A coordination polymer of $\left(\mathrm{Ph}_{3} \mathrm{P}\right) \mathrm{AuCl}$ prepared by post-synthetic modification and its application in 1-hexene/n-hexane separation. Chem. Commun. 2011, 47, 11855-11857. [CrossRef] [PubMed]

5. Sumida, K.; Rogow, D.L.; Mason, J.A.; McDonald, T.M.; Bloch, E.D.; Herm, Z.R.; Bae, T.-H.; Long, J.R. Carbon Dioxide Capture in Metal-Organic Frameworks. Chem. Rev. 2012, 112, 724-781. [CrossRef] [PubMed]

6. Canivet, J.; Fateeva, A.; Guo, Y.; Coasne, B.; Farrusseng, D. Water adsorption in MOFs: Fundamentals and applications. Chem. Soc. Rev. 2014, 43, 5594-5617. [CrossRef] [PubMed]

7. Lara-García, H.A.; Gonzalez, M.R.; González-Estefan, J.H.; Sánchez-Camacho, P.; Lima, E.; Ibarra, I.A. Removal of $\mathrm{CO}_{2}$ from $\mathrm{CH}_{4}$ and $\mathrm{CO}_{2}$ capture in the presence of $\mathrm{H}_{2} \mathrm{O}$ vapour in NOTT-401. Inorg. Chem. Front. 2015, 2, 442-447. [CrossRef]

8. Benoit, V.; Chanut, N.; Pillai, R.S.; Benzaqui, M.; Beurroies, I.; Devautour-Vinot, S.; Serre, C.; Steunou, N.; Maurin, G.; Llewellyn, P.L. A promising metal-organic framework (MOF), MIL-96(Al), for $\mathrm{CO}_{2}$ separation under humid conditions. J. Mater. Chem. A 2018, 6, 2081-2090. [CrossRef]

9. González-Zamora, E.; Ibarra, I.A. $\mathrm{CO}_{2}$ capture under humid conditions in metal-organic frameworks. Mater. Chem. Front. 2017, 1, 1471-1484. [CrossRef]

10. Wu, H.; Gong, Q.; Olson, D.H.; Li, J. Commensurate Adsorption of Hydrocarbons and Alcohols in Microporous Metal Organic Frameworks. Chem. Rev. 2012, 112, 836-868. [CrossRef] [PubMed]

11. Saccoccia, B.; Bohnsack, A.M.; Waggoner, N.W.; Cho, K.H.; Lee, J.S.; Hong, D.Y.; Lynch, V.M.; Chang, J.S.; Humphrey, S.M. Separation of $p$-Divinylbenzene by Selective Room-Temperature Adsorption Inside Mg-CUK-1 Prepared by Aqueous Microwave Synthesis. Angew. Chem. Int. Ed. 2015, 54, 5394-5398. [CrossRef] [PubMed]

12. Sagastuy-Breña, M.; Mileo, P.G.M.; Sánchez-González, E.; Reynolds, J.E., III; Jurado-Vázquez, T.; Balmaseda, J.; González-Zamora, E.; Devautour-Vinot, S.; Humphrey, S.M.; Maurin, G.; et al. Humidity-induced $\mathrm{CO}_{2}$ capture enhancement in Mg-CUK-1. Dalton Trans. 2018, 47, 15827-15834. [CrossRef] [PubMed]

13. Sánchez-González, E.; Mileo, P.G.M.; Sagastuy-Breña, M.; Álvarez, J.R.; Reynolds, J.E., III; Villareal, A.; Guitiérrez-Alejandre, A.; Ramírez, J.; Balmaseda, J.; González-Zamora, E.; et al. Highly reversible sorption of $\mathrm{H}_{2} \mathrm{~S}$ and $\mathrm{CO}_{2}$ by an environmentally friendly Mg-based MOF. J. Mater. Chem. A 2018, 6, 16900-16909. [CrossRef]

14. Laligant, Y.; Le Bail, A.; Goutenoire, F. Ab Initio Structure Determination of Lanthanum Cyclo-tetratungstate $\alpha-\mathrm{La}_{2} \mathrm{~W}_{2} \mathrm{O}_{9}$ from X-ray and Neutron Powder Diffraction. J. Solid State Chem. 2001, 159, 223-227. [CrossRef]

15. Riosnel, T.; Gonzalez-Platas, J.; Rodriguez-Carvajal, J. WinPlotr and FullProf Suite Program, ver. 3.00. 2015. Available online: https://www.ill.eu/sites/fullprof (accessed on 28 June 2017). 
16. Peralta, R.A.; Campos-Reales-Pineda, A.; Pfeiffer, H.; Álvarez, J.R.; Zárate, J.A.; Balmaseda, J.; González-Zamora, E.; Martínez, A.; Martínez-Otero, D.; Jancik, V.; et al. $\mathrm{CO}_{2}$ capture enhancement in InOF-1 via the bottleneck effect of confined ethanol. Chem. Commun. 2016, 52, 10273-10276. [CrossRef] [PubMed]

17. Sánchez-González, E.; González-Zamora, E.; Martínez-Otero, D.; Jancik, V.; Ibarra, I.A. Bottleneck Effect of $\mathrm{N}, \mathrm{N}$-Dimethylformamide in InOF-1: Increasing $\mathrm{CO}_{2}$ Capture in Porous Coordination Polymers. Inorg. Chem. 2017, 56, 5863-5872. [CrossRef] [PubMed]

(C) 2020 by the authors. Licensee MDPI, Basel, Switzerland. This article is an open access article distributed under the terms and conditions of the Creative Commons Attribution (CC BY) license (http://creativecommons.org/licenses/by/4.0/). 